\title{
Enhanced Antibacterial Activity of Se Nanoparticles Upon Coating with Recombinant Spider Silk Protein eADF4(к/6)
}

This article was published in the following Dove Press journal: International Journal of Nanomedicine

\author{
Tao Huang (D) ${ }^{1,2}$ \\ Sushma Kumari $\mathbb{D D}^{2}$ \\ Heike Herold (iD ${ }^{2}$ \\ Hendrik Bargel $\mathbb{D}^{2}$ \\ Tamara B Aigner ${ }^{2}$ \\ Daniel E Heath (D) ${ }^{\prime}$ \\ Neil M O'Brien-Simpson ${ }^{3}$ \\ Andrea J O'Connor (D) \\ Thomas Scheibel $\mathbb{D}^{2,4}$ \\ 'Department of Biomedical Engineering, \\ Melbourne School of Engineering, \\ University of Melbourne, Parkville, VIC \\ 3010, Australia; ${ }^{2}$ Department for \\ Biomaterials, Faculty of Engineering \\ Science, University of Bayreuth, Prof. \\ Rüdiger Bormann Str. I, Bayreuth 95447, \\ Germany; ${ }^{3}$ Melbourne Dental School and \\ the Bio2I Institute of Molecular Science \\ and Biotechnology, The University of \\ Melbourne, Parkville, VIC 30I0, \\ Australia; ${ }^{4}$ Bavarian Polymer Institute \\ (BPI), Bayreuth Center for Material \\ Science and Engineering (BayMAT), \\ Bayreuth Center for Colloids and \\ Interfaces (BZKG), Bayreuth Center for \\ Molecular Biosciences (BZMB), \\ University of Bayreuth, Bayreuth 95447, \\ Germany
}

Correspondence: Andrea J O'Connor; Thomas Scheibel

Tel +6I 38344 8962; +49 (0)92I/55-670I

Email a.oconnor@unimelb.edu.au;

thomas.scheibel@bm.uni-bayreuth.de
Purpose: Selenium nanoparticles (Se NPs) are promising antibacterial agents to tackle the growing problem of antimicrobial resistance. The aim of this study was to fabricate Se NPs with a net positive charge to enhance their antibacterial efficacy.

Methods: Se NPs were coated with a positively charged protein - recombinant spider silk protein eADF4 $(\kappa 16)$ - to give them a net positive surface charge. Their cytotoxicity and antibacterial activity were investigated, with negatively charged polyvinyl alcohol coated Se

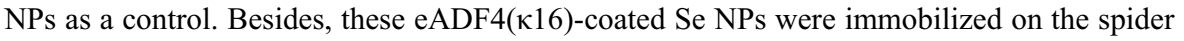
silk films, and the antibacterial activity of these films was investigated.

Results: Compared to the negatively charged polyvinyl alcohol coated Se NPs, the positively charged eADF4( $\kappa 16)$-coated Se NPs demonstrated a much higher bactericidal efficacy against the Gram-negative bacteria E. coli, with a minimum bactericidal concentration (MBC) approximately 50 times lower than that of negatively charged Se NPs. Cytotoxicity testing showed that the eADF4(к16)-coated Se NPs are safe to both Balb/3T3 mouse embryo fibroblasts and $\mathrm{HaCaT}$ human skin keratinocytes up to $31 \mu \mathrm{g} / \mathrm{mL}$, which is much higher than the MBC of these particles against E. coli $(8 \pm 1 \mu \mathrm{g} / \mathrm{mL})$. In addition, antibacterial coatings were created by immobilising the eADF4( $\kappa 16)$-coated Se NPs on positively charged spider silk films and these were shown to retain good bactericidal efficacy and overcome the issue of low particle stability in culture broth. It was found that these Se NPs needed to be released from the film surface in order to exert their antibacterial effects and this release can be regulated by the surface charge of the film, such as the change of the spider silk protein used. Conclusion: Overall, eADF4(к16)-coated Se NPs are promising new antibacterial agents against life-threatening bacteria.

Keywords: Gram-positive, Gram-negative, E. coli, antibacterial film, cytotoxicity

\section{Introduction}

Bacterial infections are a major cause of chronic wounds and mortality. ${ }^{1}$ Currently used antibiotics kill bacteria mainly targeting cell wall synthesis, translational machinery, or DNA replication machinery. ${ }^{1}$ However, bacteria can develop resistance to antibiotics by producing modified enzymes that decompose antibiotics, ${ }^{2}$ changing cell components to inhibit antibiotic interaction, ${ }^{3}$ and increase the expression of efflux pumps to excrete different types of antibiotics. ${ }^{4}$ In recent years, excessive use of antibiotics has induced the rapid development of drug-resistant bacteria. ${ }^{5}$ Bacteria resistant to all antibiotics (pandrug-resistant bacteria) have already been reported. ${ }^{6}$ These multidrug-resistant bacteria have become a potential 
global public health threat. Therefore, new antibacterial strategies are urgently needed to tackle the growing problem of these pandrug-resistant bacteria, the so-called "superbugs".

Nanoparticles (NPs) are considered to be promising antimicrobial agents to kill antibiotic-resistant bacteria, as most of the antibiotic resistance mechanisms have very limited effect on NPs. ${ }^{1}$ Several types of NPs have been explored for antimicrobial applications, such as Ag NPs, ${ }^{7}$ Au NPs, ${ }^{8} \mathrm{Se} N P s,{ }^{9} \mathrm{Pd} \mathrm{NPs},{ }^{10} \mathrm{Ti}_{2} \mathrm{O}$ NPs,${ }^{11} \mathrm{CuO}$ NPs,${ }^{12}$ and so on. Among these NPs, the antibacterial Se NPs have attracted increasing attention, with studies showing promising antimicrobial activities against bacteria and fungi ${ }^{13-16}$ as well as the ability to disrupt biofilms. ${ }^{17}$ Unlike $\mathrm{Ag}, \mathrm{Au}, \mathrm{Pd}$ and $\mathrm{Ti}$, selenium is a trace element in the human body. ${ }^{18}$ It is an important component in at least 25 selenoenzymes and a cofactor for glutathione peroxidases and thioredoxin reductases. ${ }^{19} \mathrm{Ag}$ NPs, as the most widely researched nanoparticles for antibacterial applications exhibit excellent antibacterial activity, but at the same time, show high toxicity to human cell lines. ${ }^{20,21}$ Our previous work compared the cytotoxicity and antibacterial activity of chitosan/polyvinyl alcohol scaffolds loaded with either Ag NPs or Se NPs. Both types of scaffolds showed antibacterial activity, but the scaffolds decorated with Se NPs were more cytocompatible with fibroblasts than the Ag NPs loaded scaffolds. ${ }^{22}$ Recent reports from our group ${ }^{9,23}$ and others ${ }^{24,25}$ showed that negatively charged Se NPs showed strong antibacterial effects against Gram-positive bacteria but were less effective against Gram-negative bacteria. The electrostatic attraction between positively charged nanoparticles and the negatively charged membranes of bacterial cells plays an important role in the antibacterial activity of nanoparticles. ${ }^{26,27}$ Since the membrane of Gram-negative bacteria is generally more negatively charged than that of Gram-positive bacteria, ${ }^{28,29}$ they have been observed to be more sensitive to positively charged nanoparticles. ${ }^{28}$ Therefore, positively charged nanoparticles have been explored for effective antibacterial applications. ${ }^{30-32}$ For example, Liu et al reported that positively charged Ag NPs showed a much lower minimum inhibitory concentration (MIC) than negatively charged Ag NPs against the Grampositive bacteria Bacillus subtilis, the Gram-negative bacteria $E$. coli, and the pathogenic yeast Candida albicans. ${ }^{33}$ Thus, modifying the surface of Se NPs with positive charge is a promising approach to improve the antibacterial activity of Se NPs against Gram-negative bacteria.
However, most previous studies on antibacterial Se NPs have used negatively charged coatings to stabilize the particles. $^{9,23-25,34}$ One study that did use a positively charged chitosan coating on Se NPs did not find that it improved their antibacterial efficacy over negatively charged polyvinyl alcohol (PVA)-coated Se NPs. In fact, the chitosan coated Se NPs were found to show much higher MIC than the PVA coated Se NPs against both S. aureus $(500 \mu \mathrm{g} / \mathrm{mL}$ vs $125 \mu \mathrm{g} / \mathrm{mL})$ and E. coli $(500$ $\mu \mathrm{g} / \mathrm{mL}$ vs $250 \mu \mathrm{g} / \mathrm{mL}) .{ }^{35}$ This unexpected result may be due to different sized NPs being used with the different coatings (195 nm for the chitosan coated Se NPs vs 136 $\mathrm{nm}$ for the PVA coated Se NPs). Importantly, size is one key factor influencing the uptake of NPs by cells in general and the antibacterial efficacy of Se NPs in particular. ${ }^{23}$ Another factor could be surface charge, as a positively charged surface coating has been shown to increase the uptake of Se NPs by cancer cells. ${ }^{36}$ Thus, the influence of positive charge on cytotoxicity and antibacterial activity of Se NPs still needs to be investigated.

Several synthetic and biopolymers with positive charge have been previously used as coatings of inorganic nanoparticles to enhance the antimicrobial activity, such as branched polyethyleneimine (PEI), ${ }^{37}$ poly-allylamine hydrochloride (PAH),${ }^{38}$ chitosan ${ }^{39,40}$ and oligochitosan. ${ }^{41}$ The PEI has disadvantages including toxicity and nonbiodegradability. ${ }^{42}$ PAH has high toxicity toward various mammalian cells. ${ }^{43}$ Although chitosan has good biocompatibility and antibacterial activity, ${ }^{44}$ its physical properties are highly $\mathrm{pH}$ dependent. ${ }^{45}$ To overcome the poor solubility, water soluble oligochitosan has been made by hydrolysis of chitosan. ${ }^{46}$ However, the yields of oligochitosan were often low and lead to a mixture of products. ${ }^{46,47}$ Moreover, since chitin is sourced from shellfish, and chitosan and oligochitosan are derivatives of chitin, their use may not be appropriate for people with shellfish allergies. ${ }^{48}$ Compared to these poly-

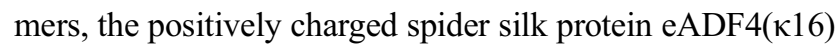
has several advantages, including good biocompatibility, low immunogenicity, nontoxicity, and biodegradability. ${ }^{49-54}$ Recombinant spider silk protein eADF4( $\kappa 16)$ is a variant of polyanionic eADF4(C16), where the naturally occurring glutamic acid residue in the sequence of the eADF4 core C-module (GSSAAA AAAAAS GPGGYG PENQGP SGPGGYGPGGP) is replaced with lysine. ${ }^{49}$ eADF4(C16) is based on the consensus core sequence of the garden spider Araneus diadematus dragline silk fibroin 4 (ADF4) and comprises a consensus (C) module repeated 16 times. ${ }^{55}$ Importantly, both recombinant spider silk proteins have 
similar physiochemical properties and therefore can be processed into several morphologies like particles, films, coatings, and fibers. ${ }^{56}$ These properties show that recombinant spider silk can be used as a suitable biopolymer to modify the surface charge of nanoparticles to enhance their antibacterial activity.

In this work, the positively charged spider silk protein eADF4(к16) was selected to stabilize Se NPs and provide a net positive surface charge. Se NPs coated

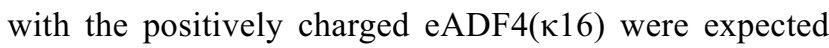
to show increased interactions with negatively charged bacterial cell membranes. Their antibacterial properties against Gram-negative bacteria, such as E. coli, and cytotoxicity for mammalian cells were assessed. In addition, PVA coated Se NPs were studied in comparison to

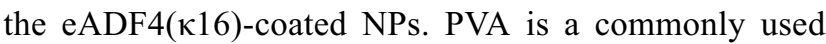
stabilizing agent for Se NPs, ${ }^{57,58}$ and the antibacterial activity of PVA coated Se NPs have been investigated in many studies. ${ }^{9,23,35,59}$ Furthermore, the eADF4(к16)coated NPs were immobilised on positively or negatively charged spider silk protein films, and their ability to exert their antibacterial activity was assessed.

\section{Materials and Methods Materials}

Selenium dioxide $\left(\mathrm{SeO}_{2}, 98 \%\right.$ ), PVA (MW 9000-10000, 80\% hydrolysed), formic acid ( $\geq 98 \%$ ) and Mueller-Hinton broth were purchased from Sigma Aldrich (Germany). ${ }^{2}$-ascorbic acid ( $\geq 99 \%)$ and agar was obtained from Roth Carl Roth GmbH (Germany). 1,1,1,3,3,3-Hexafluoro-2-propanol (HFIP, 99+\%) was purchased from Alfa Aesar (Germany). Dimethyl sulfoxide (DMSO, $\geq 99.5 \%$ ) was bought from Fluka (Australia). Phosphate-buffered saline (PBS) tablets were bought from Gibco (UK). In all the experiments, ultrapure water from a Milli-Q-system (Billerica, MA, USA) was used.

Proteins: eADF4(C16) was purchased from AMSilk GmbH (Planegg/München, Germany). eADF4(к16) was produced and purified as described previously. ${ }^{49,55}$

\section{Se NPs Synthesis}

For fabrication of positively charged Se NPs, the recombinant spider silk protein eADF4(к16) was first dissolved in formic acid ( $\geq 98 \%$ ) at a concentration of $4 \mathrm{mg} / \mathrm{mL}$ and further diluted with water to obtain a concentration of $0.1 \mathrm{mg} / \mathrm{mL}$. $\mathrm{SeO}_{2}$ powder was added into this solution to a concentration of $5 \mathrm{mM}$. Then, $4 \mathrm{~mL}$ of $0.1 \mathrm{M}_{\mathrm{L}}$-ascorbic acid was added into $4 \mathrm{~mL}$ of $0.1 \mathrm{mg} / \mathrm{mL}$ eADF4(К16) and
$5 \mathrm{mM} \mathrm{SeO}_{2}$ solution. The reaction mixture was stirred at a speed of $300 \mathrm{rpm}$ using a magnetic stirrer. After $10 \mathrm{~min}$, the solution was transferred into $2 \mathrm{~mL}$ Eppendorf tubes and was centrifuged at a speed of 13,300 rpm (17,000 g) for 3 min using a Heraeus Pico 17 centrifuge (Thermo Scientific), followed by removal of supernatant and washing the particles twice with water. Particles were stored in water for all experiments. Similarly, negatively charged Se NPs were fabricated using PVA dissolved in water at a concentration of $2 \mathrm{mg} / \mathrm{mL}$.

\section{Characterization of Se NPs}

The zeta potential of Se NPs was measured using a Zetasizer (Malvern, ATA Scientific). Zeta potential was measured at $25^{\circ} \mathrm{C}$; selenium with a refractive index (RI) of 2.6 and absorption of 0.5 was set as the material, a dielectric constant of 78.5 for water as the dispersant. ${ }^{60}$ The morphology of the Se NPs was observed using transmission electron microscopy (TEM, JEOL, Japan) at an accelerating voltage of 80 $\mathrm{keV}$. The particle sizes were determined by measuring 200 nanoparticles from more than 4 TEM images of each sample in different areas. Energy Dispersive Spectroscopy (EDS) within an equipped-on scanning electron microscope (SEM, Zeiss Sigma 300 VP, Oberkochen, Germany) was used to detect the component elements of the nanoparticles. The interaction between Se NPs and eADF4(к16) or PVA was investigated by measuring their Attenuated Total ReflectionFourier Transform Infrared (ATR-FTIR) Spectra in the range of $4000-800 \mathrm{~cm}^{-1}$ on a Bruker Tensor 27 spectrometer (Bruker, Germany). For each spectrum, 100 scans were recorded at a resolution of $4 \mathrm{~cm}^{-1}$. The individual secondary structure elements were determined by analysing the amide I region (1595-1705 $\mathrm{cm}^{-1}$ ) with Fourier self-deconvolution (FSD) using Opus software (Bruker, Germany). To measure the Se concentration of the Se NPs solutions, nitric acid $\left(\mathrm{HNO}_{3}\right)$ was used to dissolve the Se NPs into ions, and ICPOES (Perkin Elmer Optima 7300 DV, USA) was adopted to test the Se ion concentrations.

\section{Cytotoxicity Tests of Se NPs}

AlamarBlue $^{\circledR}$ was used to test the cytotoxicity of Se NPs. Balb/3T3 mouse embryo fibroblasts and HaCaT human skin keratinocytes (European Collection of Cell Cultures) were used to evaluate the cytotoxicity of Se NPs. The cells were cultured in Dulbecco's modified Eagle's medium (DMEM) with $10 \%$ fetal bovine serum (FBS), $100 \mathrm{U} \cdot \mathrm{mL}^{-1}$ gentamycin and $100 \mu \mathrm{g} \cdot \mathrm{mL}^{-1}$ glutamine, $5 \% \mathrm{CO}_{2}, 95 \%$ relative humidity, and at $37^{\circ} \mathrm{C}$. 
Se NPs solution at a concentration of $500 \mu \mathrm{g} / \mathrm{mL}$ in water was serially diluted with DMEM from concentrations of 0.97 to $31.2 \mu \mathrm{g} / \mathrm{mL}$. The control groups comprised DMEM medium as the negative control and DMEM with $10 \%(\mathrm{v} / \mathrm{v})$ DMSO as the positive control, according to ISO 10993-5 standard. ${ }^{61}$ Cells at a density of $5 \times 10^{3}$ per $100 \mu \mathrm{L}$ medium per well were added into the 96-well plates and incubated for $24 \mathrm{~h}$ at $37^{\circ} \mathrm{C}$ to allow attachment. The medium was then replaced by $100 \mu \mathrm{L}$ of DMEM with Se NPs or control media. After $24 \mathrm{~h}$ incubation, the DMEM with Se NPs was removed and washed once by PBS. Then, $120 \mu \mathrm{L}$ of DMEM with $10 \%$ alamarBlue $^{\circledR}$ reagent was added to all wells and incubated at $37^{\circ} \mathrm{C}$. After an incubation time period of $3 \mathrm{~h}, 100 \mu \mathrm{L}$ medium was transferred from each well to a black 96-well plate. The transformation of the blue fluorescent dye resazurin into red fluorescent resorufin $(\lambda \mathrm{ex}=530 \mathrm{~nm} ; \lambda \mathrm{em}=590$ $\mathrm{nm}$ ) was measured using a plate reader (Mithras LB 940, Bertold, Bad Wildbach, Germany) with $530 \mathrm{~nm}$ excitation and $600 \mathrm{~nm}$ emission filters and a counting time of 0.5 s. The cell viability $(X)$ of each experimental group was calculated based on three samples using the formula below according to ISO $10993-5 .^{61}$

$$
X=\frac{\left(O D_{1}-O D_{b}\right)}{\left(O D_{2}-O D_{b}\right)} \times 100 \%
$$

where $\mathrm{OD}_{1}$ represents the mean fluorescence density of the experimental groups or the positive control group, $\mathrm{OD}_{2}$ represents the mean fluorescence density of the negative control group, $\mathrm{OD}_{\mathrm{b}}$ represents the mean fluorescence density of the blank control.

\section{Antibacterial Tests of Se NPs}

Colony-forming units (CFU) assays using Escherichia coli (E. coli, strain BL21-Gold, Novagen, Merck, Germany) were performed for testing the antibacterial activity of Se NPs and the particles made of plain eADF4(к16). Firstly, a single colony of $E$. coli taken from an agar plate was inoculated into $20 \mathrm{~mL}$ Mueller Hinton Broth (MHB) and was cultured overnight at $37^{\circ} \mathrm{C}$. Then $200 \mu \mathrm{L}$ of the overnight bacterial solution was transferred into $10 \mathrm{~mL}$ fresh MHB and cultured for $4 \mathrm{~h}$ at $37^{\circ} \mathrm{C} .100 \mu \mathrm{L}$ of water with

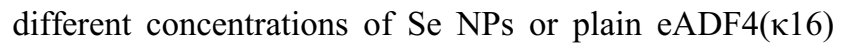
particles was added into each well of 96-well plates. The bacteria were centrifuged at $13,300 \mathrm{rpm}(17,000 \mathrm{~g})$ for $15 \mathrm{~min}$, then washed using water once and resuspend into water. $100 \mu \mathrm{L}$ of $1 \times 10^{7}$ cells $/ \mathrm{mL}$ of $E$. coli in water was added into each well. After $4 \mathrm{~h}$ incubation at $37^{\circ} \mathrm{C}$, the bacterial suspensions were diluted to $10^{-1}, 10^{-2}, 10^{-3}$ and $10^{-4}$ times with water, then $10 \mu \mathrm{L}$ of these solutions were transferred to agar plates with MHB. The agar plates were incubated overnight at $37{ }^{\circ} \mathrm{C}$, then the bacterial colony forming units were observed and counted. The minimum bactericidal concentration (MBC) was calculated according to the method published previously ${ }^{62}$. Concentrationkilling curves were plotted with CFUs $/ \mathrm{mL}$ as a function of antibacterial agent concentration, and linear regression analysis was used to determine the lowest concentration (MBC) at which the $\mathrm{CFU} / \mathrm{mL}$ becomes zero.

\section{Bacterial Morphology Imaging}

The morphology of E. coli cells after treatment with $\mathrm{Se}$ NPs was imaged using SEM (Zeiss Sigma 300 VP, Oberkochen, Germany). The samples were prepared as follows: $100 \mu \mathrm{L}$ of $150 \mu \mathrm{g} / \mathrm{mL}$ Se NPs in water was added into each well of 96-well plates, then $100 \mu \mathrm{L}$ MHB with $5 \times 10^{7}$ cells $/ \mathrm{mL}$ bacteria was added into each well. After $2 \mathrm{~h}$ incubation, $10 \mu \mathrm{L}$ of the bacteria with Se nanoparticles solution was dropped onto a clean silicon wafer, followed by drying at $37^{\circ} \mathrm{C}$ for $40 \mathrm{~min}$. Afterwards, $2.5 \% \mathrm{v} / \mathrm{v}$ glutaraldehyde was used to fix the bacteria cells for $1 \mathrm{~h}$, then gradient ethanol solutions $(30 \%, 50 \%, 60 \%$, $70 \%, 80 \%, 90 \%, 95 \%$ and $100 \% \mathrm{v} / \mathrm{v})$ were used for dehydration. After overnight drying in the air, the samples were coated with platinum prior to imaging.

\section{Fabrication of eADF4(火।6)-Coated Se NPs Immobilized on Spider Silk Protein Films}

To prepare films, recombinant spider silk proteins eADF4

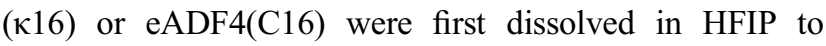
a concentration of $30 \mathrm{mg} / \mathrm{mL}$, and $10 \mu \mathrm{L}$ of the solution was dropped into each well of a 48-well plate. The samples were allowed to dry inside a fume hood and were post-treated with $70 \%$ ethanol to induce $\beta$-sheet formation. ${ }^{63,64}$ Then,

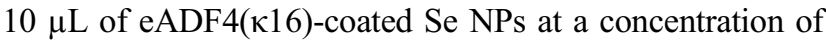
$3 \mathrm{mg} / \mathrm{mL}$ in HFIP was quickly dropped onto the films and allowed to dry in a fume hood. All the films were sterilized by UV exposure for $1 \mathrm{~h}$.

\section{Antibacterial Tests of Se NPs Immobilized on Spider Silk Protein Films}

CFU assays on E. coli were performed for testing the antibacterial activity of Se NPs immobilized on spider silk protein films. Firstly, a single colony of E. coli taken from 
an agar plate was inoculated into $20 \mathrm{~mL} \mathrm{MHB}$ and was cultured overnight at $37^{\circ} \mathrm{C}$. Then, $200 \mu \mathrm{L}$ of the overnight bacterial solution was transferred into $10 \mathrm{~mL}$ fresh MHB and cultured for $4 \mathrm{~h}$ at $37^{\circ} \mathrm{C} .250 \mu \mathrm{L}$ of $1 \times 10^{6}$ cells $/ \mathrm{mL}$ of E. coli in MHB was added into a 48 -well plate with films and incubated for $4 \mathrm{~h}$. The later steps for diluting the bacteria suspensions and culturing colonies on agar plates were the same as those used for CFU assays on Se NPs.

\section{Releasing Tests of Se NPs Immobilized on Spider Silk Protein Films}

Adhesive force between particles and substrates can be assessed qualitatively ${ }^{65}$ or quantitatively. ${ }^{66,67}$ However, for release measurements several additional factors besides simple adhesion should be taken into account, such as the flow fluids across the surfaces. Therefore, a more praxisrelated technique, as described below, was used in this work which simulated the in vivo conditions to qualitatively analyze the release properties.

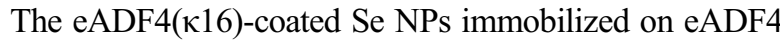
(к16) films or eADF4(C16) films were fabricated into a 48-well plate, as mentioned above. For each type of films, $250 \mu \mathrm{L}$ of MHB was added into each well of six sample wells and incubated at $37^{\circ} \mathrm{C}$ for $4 \mathrm{~h}$. In three of these six sample wells, $150 \mu \mathrm{L}$ of MHB was directly taken from each well and transferred to a $10 \mathrm{~mL}$ centrifuge tube. For the other three sample wells, $150 \mu \mathrm{L}$ of MHB was taken after 5 times pipetting from the surface of films using a $1 \mathrm{~mL}$ pipette (Eppendorf $^{\circledR}$ Research ${ }^{\circledR}$ Plus) and transferred to a $10 \mathrm{~mL}$ centrifuge tube. $350 \mu \mathrm{L} \mathrm{HNO}_{3}$ was added into each of the centrifuge tubes and allowed to react overnight to dissolve the Se NPs. Then, the solution was diluted using water and analysed by inductively coupled plasma-optical emission spectrometry (ICP-OES, Varian 720-ES) to determine the Se ion concentrations.

\section{Statistical Analysis}

Data in this work are expressed as means \pm standard deviation of three measurements. Statistical analyses for all results were performed by one-way analysis of variance (ANOVA with Tukey's Post Hoc Test using SPSS 25.0) and p-values less than 0.05 were considered statistically significant.

\section{Results and Discussion}

\section{Synthesis and Characterization of Selenium Nanoparticles}

Selenium nanoparticles (Se NPs) were synthesized by chemical reduction of selenous acid, obtained by adding selenium dioxide in water. eADF4(к16) and polyvinyl alcohol (PVA) were used as stabilizing agents and ${ }_{\mathrm{L}}$-ascorbic acid as reducing agent. TEM images of different sized Se NPs are shown in Figure 1A-B. These nanoparticles were all spherical and quite monodisperse, indicating that both

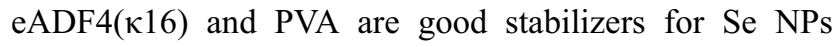
yielding a stable surface coating. The size distribution of these nanoparticles evaluated from their TEM images is shown in Figure 1C-D. The mean diameter of Se NPs

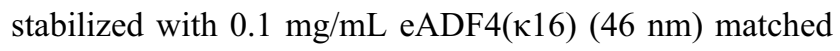
that of $2 \mathrm{mg} / \mathrm{mL}$ PVA stabilized Se NPs (46 nm). The zeta potentials of the eADF4(к16)-coated Se NPs and PVA coated Se NPs were $+46.0 \pm 0.6 \mathrm{mV}$ and $-7.3 \pm 0.1 \mathrm{mV}$, respectively. The zeta potential distributions are shown in Figure S1.

Energy Dispersive Spectroscopy (EDS) analysis of

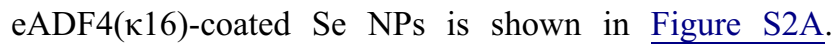
Peaks corresponding to $\mathrm{O}, \mathrm{N}$ and Se confirm the eADF4 (к16) coating of the Se NPs. Also, EDS of control samples

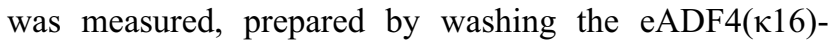
coated Se NPs with guanidinium thiocyanate, as shown in Figure S2B. Guanidinium thiocyanate denatures the protein

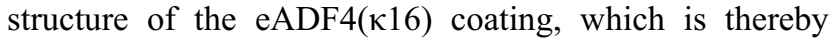
removed from the Se NP surface, leading to aggregation of Se NPs and disappearance of the nitrogen peak in the EDS. The eADF4(к16)-coated Se NPs were observed visibly to be stable in water for more than 3 months, indicating

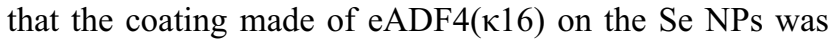
stable, preventing particle aggregation.

FT-IR was used to investigate the structural features of Se NPs and eADF4(к16), and the spectra are shown in Figure 1E.

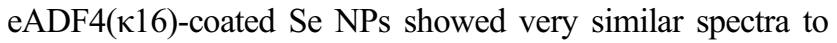

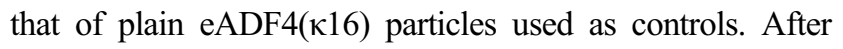
washing with guanidinium thiocyanate, the protein peaks of the coated Se NPs significantly decreased. Fourier selfdeconvoluted absorbance spectra of the amide I band of

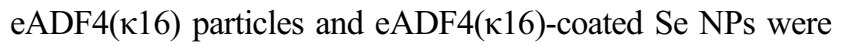
evaluated and are shown in Figure S3. The percentages of the secondary structure elements are listed in Table 1. Comparing

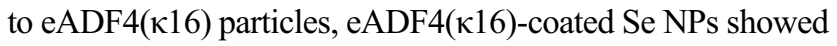
similar features with a slightly decreased percentage of side chains and increased percentage of turns.

FT-IR was also used to investigate the structural features of Se NPs coated with PVA (Figure 1F). Plain PVA showed a peak at $3307 \mathrm{~cm}^{-1}$ corresponding to $\mathrm{O}-\mathrm{H}$ stretching vibrations. The peaks at $2850 \mathrm{~cm}^{-1}$, $2920 \mathrm{~cm}^{-1}$ and $2941 \mathrm{~cm}^{-1}$ corresponded to $\mathrm{C}-\mathrm{H}$ stretching from the alkyl group. In comparison, 

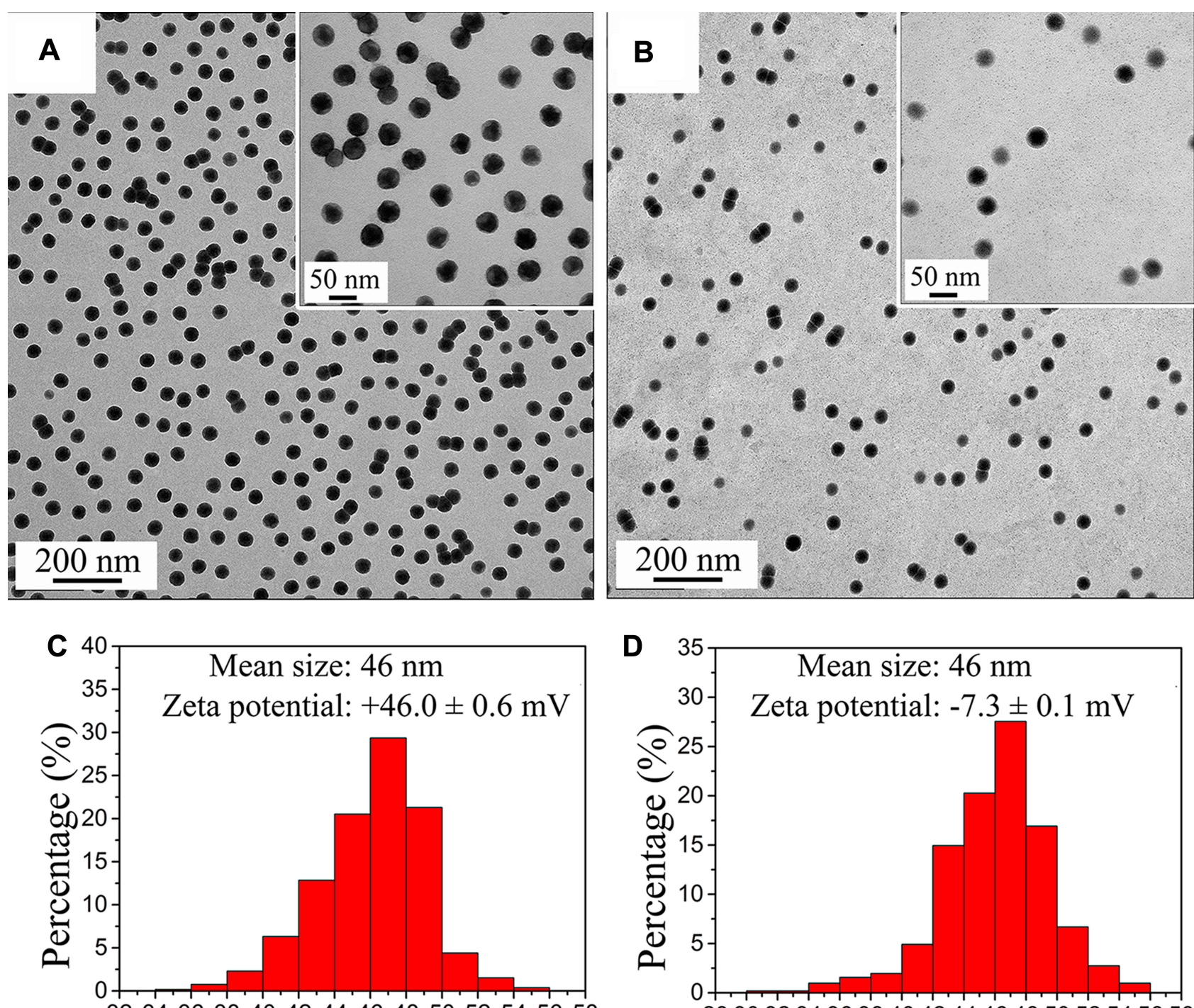

3234363840424446485052545658

Diameter (nm)
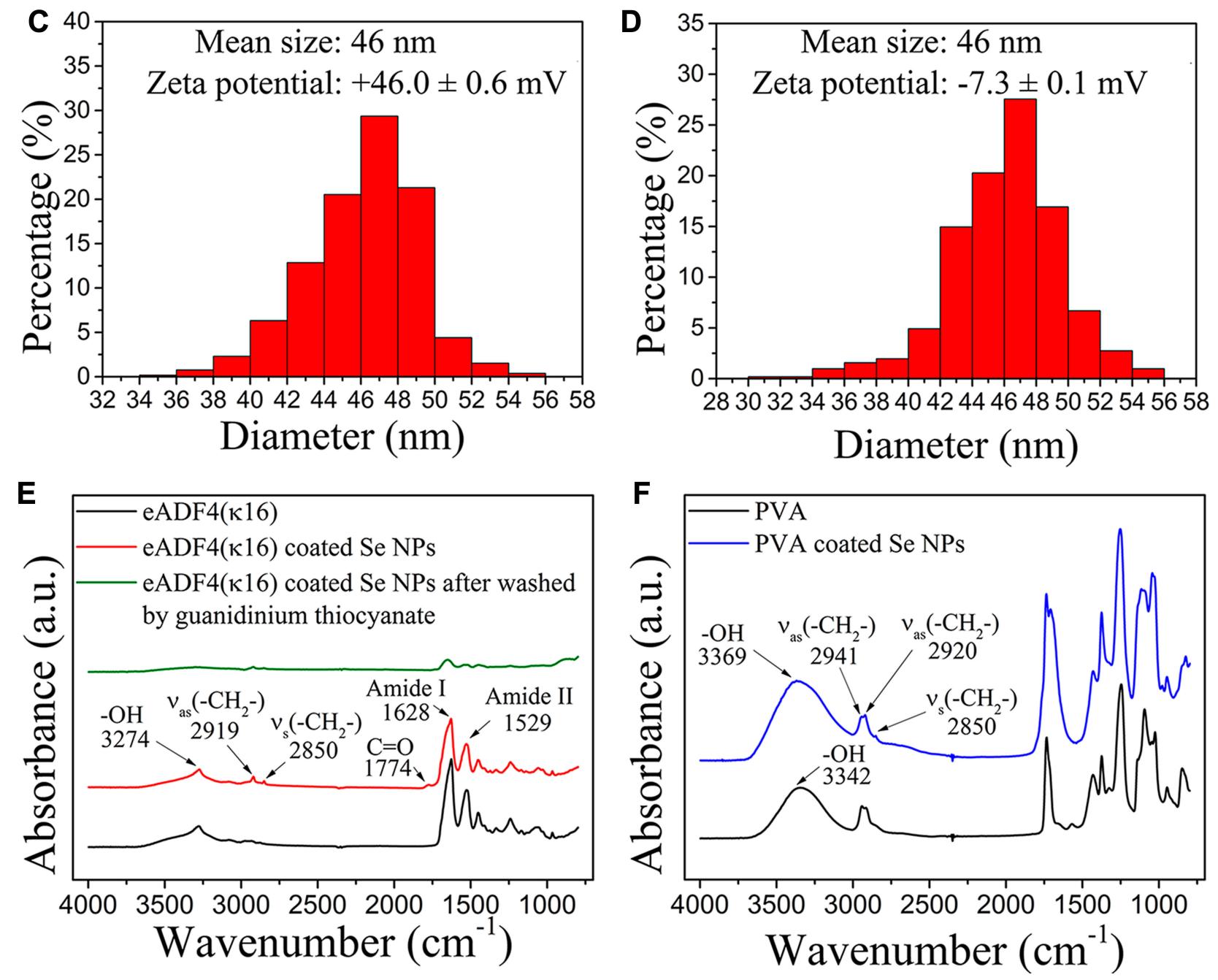

Figure I TEM images and the corresponding size distributions of Se NPs coated with (A, C) eADF4( $\kappa \mid 6)$, and (B, D) PVA. Inset images inside (A, B) are high resolution images. FT-IR spectra of Se NPs coated with (E) eADF4 $(\kappa \mid 6)$, and (F) PVA and comparisons with control spectra of eADF4( $\kappa 16)$ and PVA. 
Table I Percentages of Secondary Structure Elements of eADF4 $(\kappa \mid 6)$ and eADF4 $(\kappa \mid 6)$-Coated Se NPs Based on the Fourier SelfDeconvoluted Absorbance Spectrum of the Amide I Band

\begin{tabular}{|c|c|c|c|c|c|}
\hline \multirow[t]{2}{*}{ Samples } & \multicolumn{5}{|c|}{ Percentage of Secondary Structure Elements (\%) } \\
\hline & $\begin{array}{l}\text { Side } \\
\text { Chains }\end{array}$ & $\beta$-Sheets & $\begin{array}{l}\text { Random } \\
\text { Coils }\end{array}$ & $\alpha$-Helices & Turns \\
\hline $\begin{array}{l}\text { eADF4 }(\kappa \mid 6) \\
\text { particles }\end{array}$ & $5 \pm 1$ & $41 \pm 1$ & $24 \pm 1$ & $7 \pm 1$ & $22 \pm 1$ \\
\hline $\begin{array}{l}\text { eADF4 }(\kappa \mid 6)- \\
\text { coated Se NPs }\end{array}$ & $2 \pm 1$ & $39 \pm 2$ & $25 \pm 1$ & $9 \pm 1$ & $26 \pm 1$ \\
\hline
\end{tabular}

PVA coated Se NPs showed a shift in the hydroxyl peak to $3369 \mathrm{~cm}^{-1}$. This blue-shift indicated that PVA was conjugated to the surface of Se NPs through the $-\mathrm{OH}$ group. $^{36}$

\section{Cytotoxicity Test of Selenium Nanoparticles Using Fibroblasts and Keratinocytes}

The cell viability of Balb/3T3 mouse embryo fibroblasts and $\mathrm{HaCaT}$ human skin keratinocytes exposed to different concentrations of eADF4(к16)-coated Se NPs and PVA coated Se
NPs were measured using the alamarBlue ${ }^{\circledR}$ assay (Figure 2). Balb/3T3 mouse embryo fibroblasts are frequently used to test materials' carcinogenicity ${ }^{68}$ and cytotoxicity, ${ }^{69,70}$ and HaCaT keratinocytes are a preliminary in vitro model to investigate skin toxicity. ${ }^{71}$ Both of these cell lines have been widely used for cytotoxicity tests of nanoparticles. ${ }^{70,72-74}$ The PVA coated Se NPs exhibited no obvious cytotoxicity at concentrations up to $31.2 \mu \mathrm{g} / \mathrm{mL}$. The viability of Balb/3T3 mouse embryo fibroblasts did decrease somewhat with increasing concentrations of Se NPs, but their viability was not below $70 \%$ even at the highest dose of $31 \mu \mathrm{g} / \mathrm{mL}$ (one-sample $t$-test, $\mathrm{p}=0.41$ ). According to ISO $10993-5,{ }^{61}$ a material reducing cell viability below $70 \%$ of the negative control is considered to be potentially cytotoxic, so the effects of these Se NPs would not be classified as cytotoxic at these doses. All in all, up to $31 \mu \mathrm{g} / \mathrm{mL}$, eADF4( 16 )-coated Se NPs and PVA coated Se NPs were not considered to be potentially cytotoxic for Balb/ 3T3 mouse embryo fibroblasts.

After 24 hours' exposure, both the eADF4(к16)-coated Se NPs and the PVA coated Se NPs showed no significant cytotoxicity to the HaCaT human skin keratinocytes at doses up to $31.2 \mu \mathrm{g} / \mathrm{mL}$. The viability of HaCaT human skin keratinocytes exposed to PVA coated Se NPs showed a trend of first
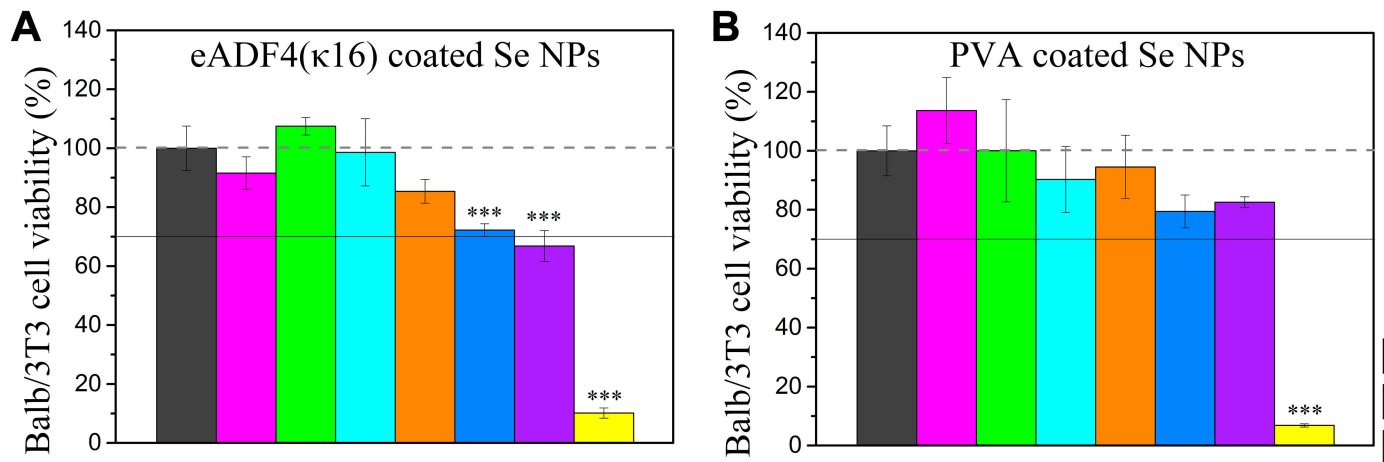

Negative control $0.97 \mu \mathrm{g} / \mathrm{mL}$ $1.95 \mu \mathrm{g} / \mathrm{mL}$ $3.9 \mu \mathrm{g} / \mathrm{mL}$
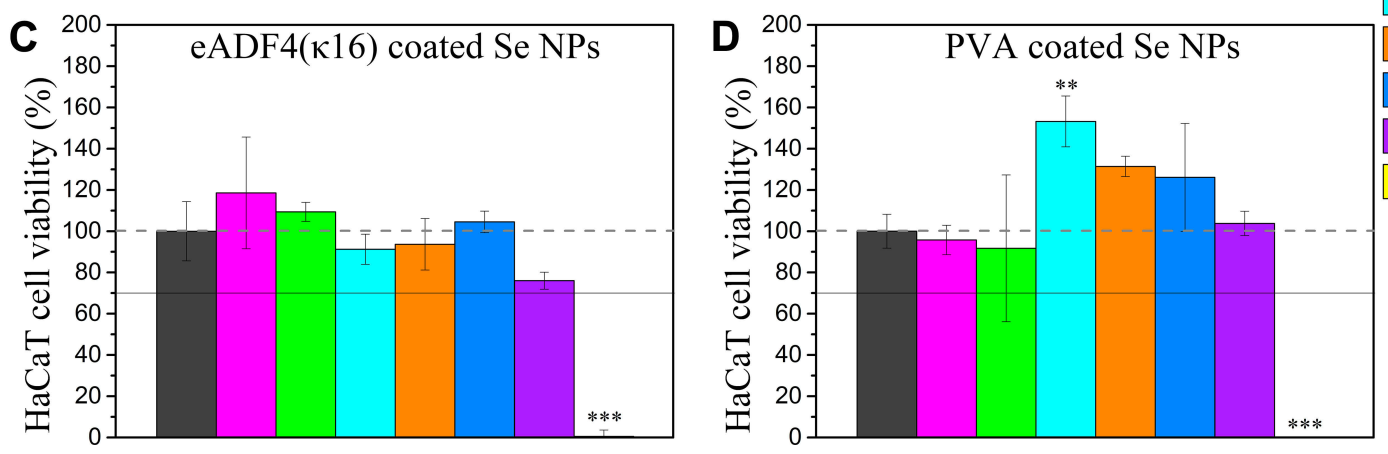

$7.8 \mu \mathrm{g} / \mathrm{mL}$

$15.6 \mu \mathrm{g} / \mathrm{mL}$

$31.2 \mu \mathrm{g} / \mathrm{mL}$

Positive control

Figure 2 Effects of Se NPs on the viability of mammalian cells in culture. Balb/3T3 mouse embryo fibroblasts incubated with (A) eADF4(אI6)-coated Se NPs, and (B) PVA

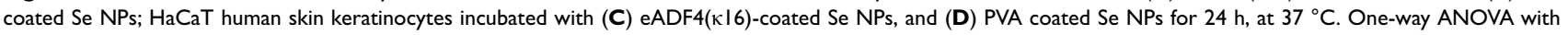
Tukey's post hoc test was used to compare means of experimental groups to that of the negative control group, **p-value $<0.0 \mathrm{I}$, $* * * \mathrm{p}$-value $<0.00 \mathrm{I}$. The dashed horizontal line represents $100 \%$ viability, and the solid line represents $70 \%$ viability. 
increasing to $153 \pm 12 \%$ with $3.9 \mu \mathrm{g} / \mathrm{mL}$ of PVA coated Se NPs and then decreasing with increasing Se concentrations. This trend, which is consistent with our previous findings, ${ }^{23}$ may be attributed to the antioxidant activity of Se NPs. ${ }^{16,75}$ At low levels, Se cannot sufficiently scavenge reactive oxygen species (ROS), whereas at high levels, Se can catalyse the production of ROS, which can be toxic to human cells, making an intermediate dose favourable. The eADF4(к16)-coated Se NPs did not show this trend, possibly due to differences in their interactions and uptake by the cells. As selenium has a very low solubility in physiological conditions, the ways the NPs themselves interact with the cells are expected to govern their effects.

The greater decrease in the viability of the Balb/3T3

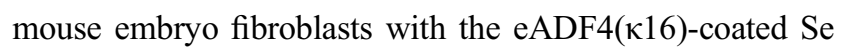
NPs compared to the PVA coated Se NPs may be ascribed to the surface charge of the Se NPs. High positive surface charge of NPs has been reported to be more cytotoxic than negative surface charge. ${ }^{76}$ The cellular uptake process can be divided into two steps: first, particles attach to the cell membrane, and second, they are internalized by the cells. ${ }^{77}$ The step of attachment is mostly affected by the surface charge of the nanoparticle. ${ }^{78,79}$ As the cell membrane is dominated by negatively charged sulphated proteoglycans, ${ }^{80}$ nanoparticles with high positive surface charge can therefore more easily approach cells and become strongly bound to the cell membrane, resulting in a higher cellular uptake. ${ }^{81}$ As the eADF4 (к16)-coated Se NPs have a high positive surface charge $(+46.0 \pm 0.6 \mathrm{mV})$, they may induce higher cellular uptake resulting in greater effects on the cells. The PVA coated Se NPs have a slightly negative surface charge $(-7.3 \pm 0.1 \mathrm{mV})$, which may reduce their ability to be taken up by the cells, consistent with them being less cytotoxic.

\section{Antibacterial Activity of Selenium Nanoparticles}

eADF4(к16)-coated Se NPs and PVA coated Se NPs were tested for their antibacterial activity against $E$. coli as a model organism. Both types of Se NPs showed dose-dependent antibacterial effects against E. coli (Figure 3A). However, the bactericidal effect of eADF4(к16)-coated Se NPs was much higher than that of its counterpart, with a minimum bactericidal concentration (MBC) against $E$. coli of $8 \pm 1 \mu \mathrm{g} / \mathrm{mL}$, which is 50 times lower than that of the PVA coated Se NPs with a MBC of $405 \pm 80 \mu \mathrm{g} / \mathrm{mL}$. Figure 3B-D shows the agar plates with E. coli colonies after treatment with Se NPs. It could be clearly shown that no colonies were detected when treated with at least
$15.6 \mu \mathrm{g} / \mathrm{mL}$ of eADF4( $\kappa 16)$-coated Se NPs. By contrast, a large number of colonies appeared even after treatment with $31.2 \mu \mathrm{g} / \mathrm{mL}$ of PVA coated Se NPs. As shown above, eADF4(к16)-coated Se NPs are safe for both Balb/3T3 mouse embryo fibroblasts and $\mathrm{HaCaT}$ human skin keratinocytes up to $31 \mu \mathrm{g} / \mathrm{mL}$, which is much higher than the MBC $(8 \pm 1 \mu \mathrm{g} / \mathrm{mL})$ of these NPs against $E$. coli. Therefore, it should be safe and effective to use these particles at doses below $31 \mu \mathrm{g} / \mathrm{mL}$ for antibacterial applications. However, further testing would be needed to confirm their biocompatibility for specific in vivo applications.

The morphologies of $E$. coli before and after treatment with the Se NPs are shown in Figure 3E-G. The negatively charged PVA coated Se NPs were repelled by E. coli (Figure 3F), whereas the eADF4(к16)-coated Se NPs were able to attach to E. coli (Figure 3G). The greater attachment of the Se NPs with the positively charged coating to $E$. coli correlates well with the lower concentration of these NPs required to show antibacterial efficacy, as demonstrated in Figure 3A. These results confirmed the importance of electrostatic attraction between positively charged nanoparticles and negatively charged membrane of bacterial cells for the antibacterial activity of nanoparticles. ${ }^{26,82}$

Particles made of plain eADF4( $\kappa 16)$ alone showed no antibacterial effects up to $250 \mu \mathrm{g} / \mathrm{mL}$ against $E$. coli (Figure S4), so the antibacterial activity of the eADF4 (к16)-coated Se NPs can be primarily attributed to their selenium content. Our previous work revealed that $\mathrm{Se}$ NPs show multi-modal mechanisms of action on Grampositive bacteria, including depletion of internal adenosine triphosphate (ATP), promotion of ROS production, and disruption of membrane potential. ${ }^{23}$ ATP is an important energy source of living organisms, the depletion of ATP can seriously affect both respiration and metabolism of bacteria. ${ }^{83,84}$ Over production of ROS can induce the damage of cellular components including lipids, DNA and proteins. ${ }^{85,86}$ Disruption of membrane potential can cause changes of a series of cellular processes. ${ }^{87}$ Chudobova et al also found that Se NPs could impair the bacterial DNA structure of the zntR gene amplified in vitro ${ }^{88}$ and Liu et al reported that $\mathrm{Se}$ NPs could weaken bacterial membranes and decrease the function of adhesion-mediating proteins. ${ }^{89}$ Tran et al proposed that the antibacterial effect of Se NPs is also related to free intracellular thiol depletion of Se NPs. ${ }^{90}$ Besides, the positive charge could enhance the interactions between NPs and cell membranes, and then induce more intense membrane damage, ${ }^{91}$ which can also be an 

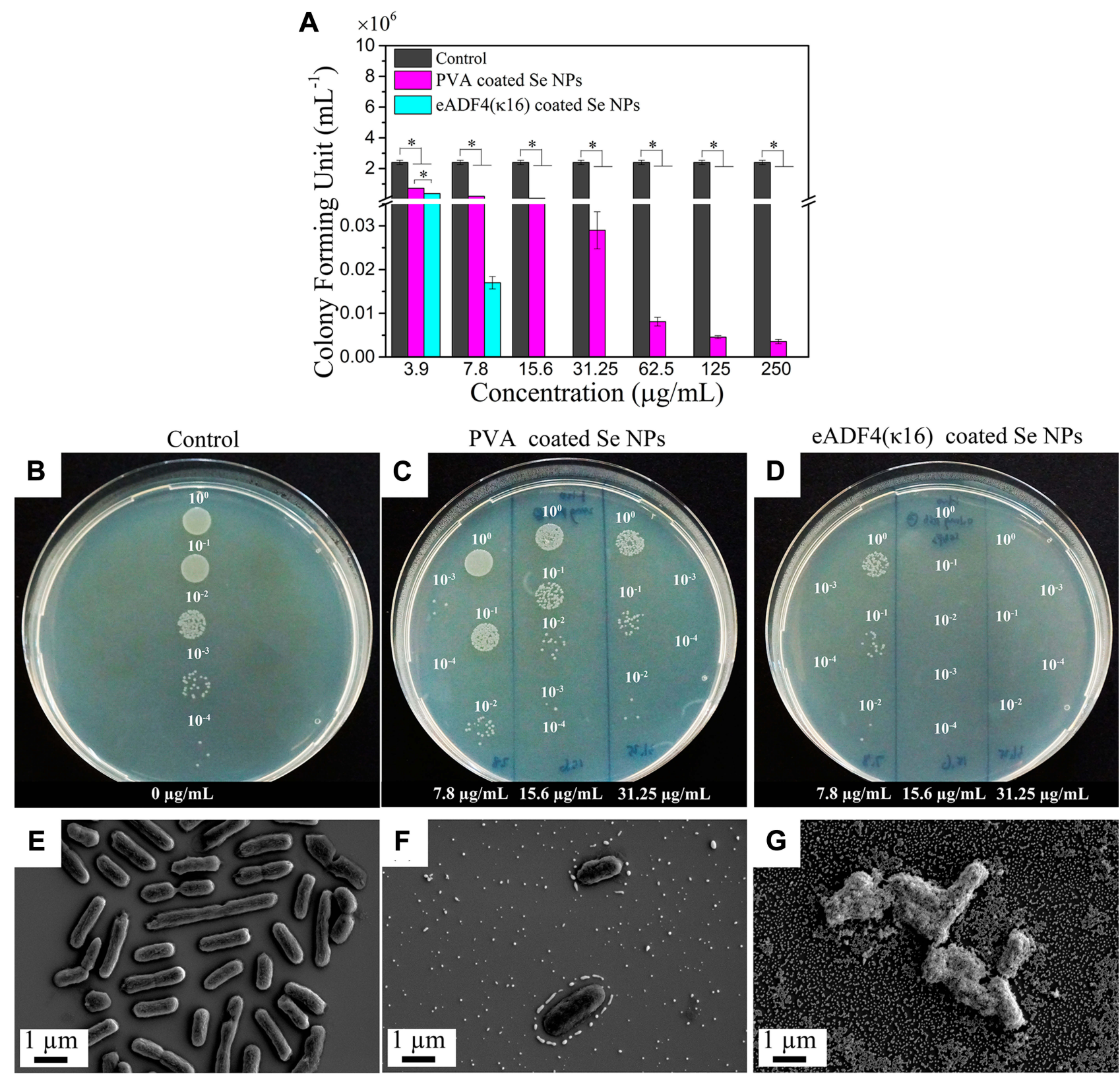

Figure 3 (A) colony-forming units (CFU) assay using E. coli after treatment with eADF4( $\kappa l 6)$ and PVA-coated Se NPs with varying concentrations from $3.9 \mu g / \mathrm{mL}$ to $250 \mu g /$ $\mathrm{mL}$. One-way ANOVA with Tukey's post hoc test was used to compare means of experimental groups at each concentration, ${ }^{*} \mathrm{p}$-value $<0.05$. (B-D) Agar plate images of CFU test of $E$. coli, (B) control without particles, (C) PVA coated Se NPs, (D) eADF4( $\kappa \mid 6)$-coated Se NPs. $10^{\circ}$ is the original (bacteria + Se NPs) solution, $10^{-1}$, $10^{-2}$, $10^{-3}$ and $10^{-4}$ mean diluting the original solution $10,100,1000$ and 10,000 times, respectively, to make the colonies more countable. SEM images of $2.5 \times 10^{7}$ cells/mL E. coli before

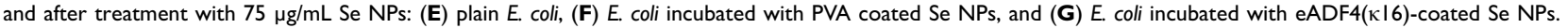

antibacterial mechanism of eADF4(к16)-coated Se NPs. Further studies would be needed to elucidate the specific mechanisms of action of eADF4(к16)-coated Se NPs.

In a previous study, PVA coated Se NPs with effective antibacterial activity against Gram-positive bacteria S. aureus were fabricated. ${ }^{23}$ However, these particles were found to be less effective against the Gram-negative bac-

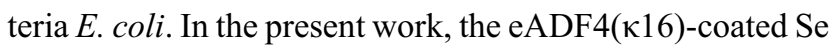
NPs showed a much higher antibacterial activity against
E. coli than PVA coated ones. Meanwhile, these particles also retained good antibacterial activity against $S$. aureus (Figure S5), with a MBC value of $32 \pm 1 \mu \mathrm{g} / \mathrm{mL}$. Notably,

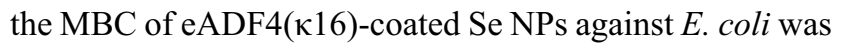
four times lower than that against $S$. aureus. Positively charged NPs often work better against Gram-negative bacteria than Gram-positive bacteria as the Gram-negative bacteria are more sensitive to positively charged materials. $^{92,93}$ The antibacterial activity of these eADF4 


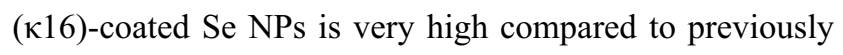
reported PVA coated Se NPs, which normally show a minimum inhibitory concentration (MIC) higher than 60 $\mu \mathrm{g} / \mathrm{mL}^{9,17,34,35}$ against $S$. aureus, and even worse performance against $E$. coli, with no significant effect, ${ }^{9,24,25,35}$ or MIC values higher than $100 \mu \mathrm{g} / \mathrm{mL} .^{17,34,94}$ Although the MBC was not tested in most of these studies, the MBC is generally higher than the MIC. By contrast, the eADF4 (к16)-coated Se NPs showed relatively low MBC values of $32 \pm 1 \mu \mathrm{g} / \mathrm{mL}$ against $S$. aureus, and $8 \pm 1 \mu \mathrm{g} / \mathrm{mL}$ against E. coli. The PVA coated Se NPs showed a MBC of $35 \pm 16$ $\mu \mathrm{g} / \mathrm{mL}$ against $S$. aureus, ${ }^{23}$ but they were found to have only weak antibacterial effects against $E$. coli as mentioned above. One study showed Se NPs with MIC of $4 \mu \mathrm{g} / \mathrm{mL}$ against both $S$. aureus and E. coli. ${ }^{95}$ However, this required additional antimicrobial compounds to boost the efficacy of Se NPs. Although the eADF4(к16)-coated Se NPs showed higher antibacterial activity than previously reported Se NPs, it is worth noting that the antibacterial tests of these eADF4(א16)-coated Se NPs were conducted in water rather than bacterial culture medium as used for other studies due

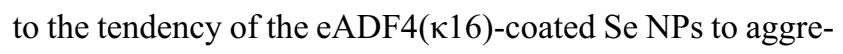
gate in bacterial culture medium.

\section{Antibacterial Test of Spider Silk Coated Se NPs Immobilized on Spider Silk Films}

The eADF4(к16)-coated Se NPs were found to quickly aggregate and deposit in Mueller-Hinton broth (MHB). MHB is a nutrient-rich medium, which is representative of the physiological environment ${ }^{96}$ and regarded to be the gold standard culture media for antibacterial susceptibility testing. ${ }^{97,98}$ Thus, in order to stabilize the particles against aggregation in MHB, they were immobilized on the surfaces of films made of the positively charged eADF4(К16) and negatively charged eADF4(C16). Physicochemical properties as well as secondary structure of spider silk films have been thoroughly characterised in previous studies. ${ }^{64,99}$ Then, the antibacterial activity of the immobilized Se NPs was tested. The charge of the films was expected to influence both the immobilization and potential release of

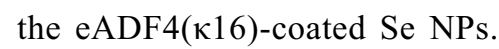

The CFU test results for $E$. coli after treatment with eADF4(к16)-coated Se NPs immobilized on the two types of spider silk protein films are shown in Figure 4A.

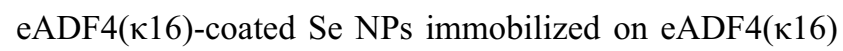
films (with the identical surface charge) showed a significant antibacterial activity, whereas particles on eADF4(C16) films (with the opposite surface charge) showed no significant difference in CFU counts relative to the control.

These results demonstrated the effect of the charge of the surface used to immobilize the coated Se NPs.

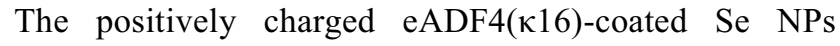
would be expected to adsorb more strongly to the negatively charged eADF4(C16) films through electrostatic

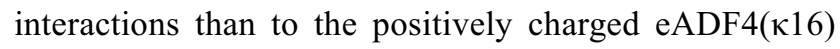
films. This was confirmed by comparison of the amounts of Se released from the two types of films with immo-

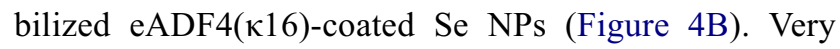
little Se was released from the films after $4 \mathrm{~h}$ under static immersion in MHB. Upon applying gentle shear
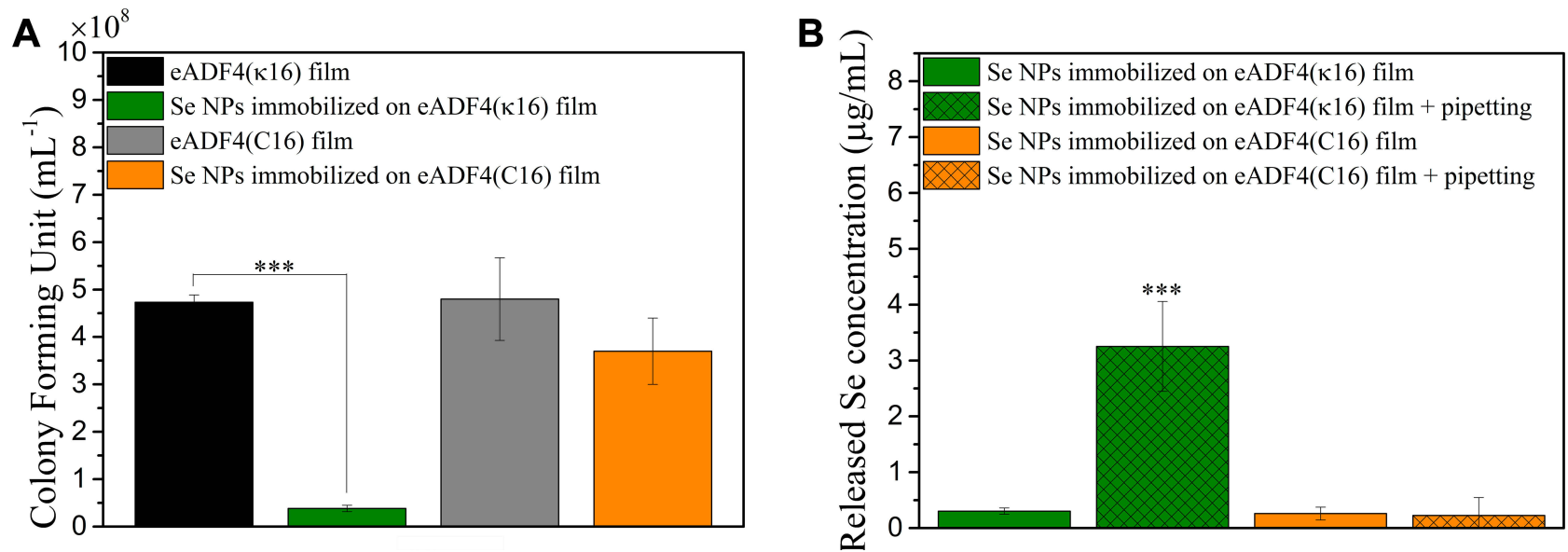

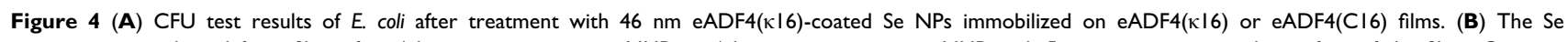
concentrations released from films after $4 \mathrm{~h}$ static immersion in MHB or $4 \mathrm{~h}$ static immersion in MHB with 5 times pipetting on the surface of the films. One-way ANOVA with Tukey's post hoc test was used to compare means of experimental groups, ***p-value $<0.00$ I. 


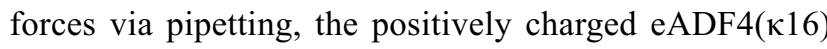
films released significant amounts of selenium into the culture broth, however, no significant release was seen from negatively charged films. Thus, the Se NPs could be more easily released from the eADF4( 116$)$ films, and this correlates with the lower CFU counts found for E. coli exposed to these films. This indicates that these Se NPs need to be released from the spider silk surface in order to exert their antibacterial effects on $E$. coli. Besides, unlike Ag NP coatings which could rely on the released silver ions to provide the antibacterial activity, ${ }^{100}$ the present work implied that Se NP coatings need to rely on NPs themselves to combat bacteria rather than operating via the release of selenium ions. This correlates well with the much lower solubility of selenium compared to that of silver. ${ }^{100,101}$ These new insights will help enable the future design of effective antibacterial surface coatings based on Se NPs.

\section{Conclusion}

Previous studies have reported that negatively charged Se NPs showed good antibacterial activity against Grampositive bacteria, but they are less effective against Gramnegative bacteria which are more sensitive to positively charged nanoparticles. In this work, positively charged eADF4(к16)-coated Se NPs and negatively charged PVA coated Se NPs with the same mean diameter $(46 \mathrm{~nm})$ were fabricated. Both the eADF4( $\kappa 16)$-coated Se NPs and PVA coated Se NPs were safe to Balb/3T3 mouse embryo fibroblasts and $\mathrm{HaCaT}$ human skin keratinocytes up to $31 \mu \mathrm{g} / \mathrm{mL}$. Comparing to PVA coated Se NPs, eADF4

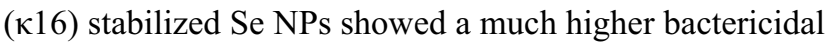
efficacy against the Gram-negative bacteria E. coli.

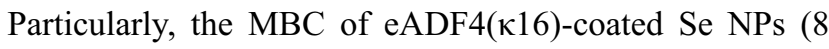
$\pm 1 \mu \mathrm{g} / \mathrm{mL}$ ) was approximately 50 times lower than that of PVA coated Se NPs $(405 \pm 80 \mu \mathrm{g} / \mathrm{mL})$. Immobilizing the

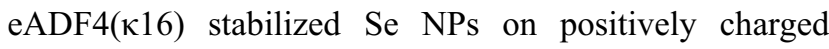
eADF4(к16) films showed a good bactericidal effect against E. coli in culture broth. Together, these results

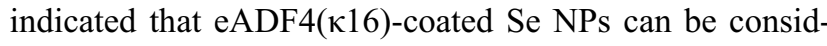
ered as promising new antibacterial agents.

\section{Acknowledgments}

The authors acknowledge financial support by the German Academic Exchange service (DAAD) through its Thematic Network Melbourne-Bayreuth Polymer/Colloid Network sponsored from funds of the Federal Ministry of Education and Research (BMBF), and European Union Grand ETZ-
EFRE 2014-2020, Freistaat Bayern-Tschechien, Project Nr. 123. Bavarian Research Foundation for financial support (DOK-175-15, T.B.A). TH gratefully acknowledges the support of the University of Melbourne and an Australian Government Research Training Program Scholarship (Melbourne International Research Scholarship).

\section{Disclosure}

Thomas Scheibel is co-founder and shareholder of AMSilk $\mathrm{GmbH}$, Germany. Tamara Aigner reports grants from Bavarian Research Foundation, during the conduct of the study. Andrea O'Connor reports non-financial support from Anatomics Pty Ltd, outside the submitted work. The authors report no other conflicts of interest in this work.

\section{References}

1. Wang $\mathrm{L}, \mathrm{Hu} \mathrm{C}$, Shao L. The antimicrobial activity of nanoparticles: present situation and prospects for the future. Int $J$ Nanomed. 2017;12:1227.

2. Poole K. Mechanisms of bacterial biocide and antibiotic resistance. $J$ Appl Microbiol. 2002;92(s1):55S-64S. doi:10.1046/j.13652672.92.5s1.8.x

3. Jayaraman R. Antibiotic resistance: an overview of mechanisms and a paradigm shift. Curr Sci. 2009;1475-1484.

4. Knetsch ML, Koole LH. New strategies in the development of antimicrobial coatings: the example of increasing usage of silver and silver nanoparticles. Polymers. 2011;3(1):340-366. doi:10.3390/ polym 3010340

5. Theuretzbacher U. Global antibacterial resistance: the never-ending story. J Glob Antimicrob Resist. 2013;1(2):63-69. doi:10.1016/j. jgar.2013.03.010

6. Basak S, Singh P, Rajurkar M. Multidrug resistant and extensively drug resistant bacteria: A study. $J$ Pathog. 2016;2016:1-5. doi:10.1155/2016/4065603

7. Ivask A, Kurvet I, Kasemets K, et al. Size-dependent toxicity of silver nanoparticles to bacteria, yeast, algae, crustaceans and mammalian cells in vitro. PLoS One. 2014;9(7):e102108. doi:10.1371/ journal.pone.0102108

8. Xie Y, Liu Y, Yang J, et al. Gold Nanoclusters for targeting methicillin-resistant staphylococcus aureus in vivo. Angew Chem Int Ed. 2018;57(15):3958-3962. doi:10.1002/anie.201712878

9. Tran PA, O'Brien-Simpson N, Reynolds EC, Pantarat N, Biswas DP, O'Connor AJ. Low cytotoxic trace element selenium nanoparticles and their differential antimicrobial properties against S. Aureus E Coli Nanotechnol. 2015;27(4):045101.

10. Adams CP, Walker KA, Obare SO, Docherty KM. Size-dependent antimicrobial effects of novel palladium nanoparticles. PLoS One. 2014;9(1):e85981. doi:10.1371/journal.pone.0085981

11. Kühn KP, Chaberny IF, Massholder K, et al. Disinfection of surfaces by photocatalytic oxidation with titanium dioxide and UVA light. Chemosphere. 2003;53(1):71-77. doi:10.1016/S00456535(03)00362-X

12. Bondarenko O, Juganson K, Ivask A, Kasemets K, Mortimer M, Kahru A. Toxicity of $\mathrm{Ag}, \mathrm{CuO}$ and $\mathrm{ZnO}$ nanoparticles to selected environmentally relevant test organisms and mammalian cells in vitro: a critical review. Arch Toxicol. 2013;87(7):1181-1200. doi:10.1007/s00204-013-1079-4 
13. Wadhwani SA, Shedbalkar UU, Singh R, Chopade BA. Biogenic selenium nanoparticles: current status and future prospects. Appl Microbiol Biotechnol. 2016;100(6):2555-2566. doi:10.1007/ s00253-016-7300-7

14. Ionin A, Ivanova A, Khmel'nitskii R, et al. Antibacterial effect of the laser-generated Se nanocoatings on Staphylococcus aureus and Pseudomonas aeruginosa biofilms. Laser Phys Lett. 2017;15 (1):015604. doi:10.1088/1612-202X/aa897f

15. Ismail A-WA, Sidkey NM, Arafa RA, Fathy RM, El-Batal AI. Evaluation of in vitro antifungal activity of silver and selenium nanoparticles against Alternaria solani caused early blight disease on potato. Br Biotechnol J. 2016;12(3):1. doi:10.9734/BBJ/2016/ 24155

16. Yazhiniprabha $M$, Vaseeharan B. In vitro and in vivo toxicity assessment of selenium nanoparticles with significant larvicidal and bacteriostatic properties. Mater Sci Eng C. 2019;103:109763. doi:10.1016/j.msec.2019.109763

17. Zonaro E, Lampis S, Turner RJ, Qazi SJS, Vallini G. Biogenic selenium and tellurium nanoparticles synthesized by environmental microbial isolates efficaciously inhibit bacterial planktonic cultures and biofilms. Front Microbiol. 2015;6:584. doi:10.3389/ fmicb.2015.00584

18. Underwood E. Trace Elements in Human and Animal Nutrition. Elsevier; 2012.

19. VlC T, Hinchman A, Williams R, Tran PA, Fox K. Nanostructured biomedical selenium at the biological interface. Biointerphases. 2018;13(6):06D301. doi:10.1116/1.5042693

20. AshaRani P, Low Kah Mun G, Hande MP, Valiyaveettil S. Cytotoxicity and genotoxicity of silver nanoparticles in human cells. ACS Nano. 2008;3(2):279-290. doi:10.1021/nn800596w

21. Tran PA, Hocking DM, O'Connor AJ. In situ formation of antimicrobial silver nanoparticles and the impregnation of hydrophobic polycaprolactone matrix for antimicrobial medical device applications. Mater Sci Eng C. 2015;47:63-69. doi:10.1016/j. msec.2014.11.016

22. Biswas DP, O'Brien-Simpson NM, Reynolds EC, O'Connor AJ, Tran PA. Comparative study of novel in situ decorated porous chitosan-selenium scaffolds and porous chitosan-silver scaffolds towards antimicrobial wound dressing application. $J$ Colloid Interface Sci. 2018;515:78-91. doi:10.1016/j.jcis.2018.01.007

23. Huang T, Holden JA, Heath DE, O'Brien-Simpson NM, O'Connor AJ. Engineering highly effective antimicrobial selenium nanoparticles through control of particle size. Nanoscale. 2019;11 (31):14937-14951. doi:10.1039/C9NR04424H

24. Bartůněk V, Junková J, Šuman J, et al. Preparation of amorphous antimicrobial selenium nanoparticles stabilized by odor suppressing surfactant polysorbate 20. Mater Lett. 2015;152:207-209. doi:10.1016/j.matlet.2015.03.092

25. Nguyen TH, Vardhanabhuti B, Lin M, Mustapha A. Antibacterial properties of selenium nanoparticles and their toxicity to Caco-2 cells. Food Control. 2017;77:17-24. doi:10.1016/j.foodcont. 2017.01.018

26. Stoimenov PK, Klinger RL, Marchin GL, Klabunde KJ. Metal oxide nanoparticles as bactericidal agents. Langmuir. 2002;18 (17):6679-6686. doi:10.1021/la0202374

27. Radovic-Moreno AF, Lu TK, Puscasu VA, Yoon CJ, Langer R, Farokhzad OC. Surface charge-switching polymeric nanoparticles for bacterial cell wall-targeted delivery of antibiotics. ACS Nano. 2012;6(5):4279-4287. doi:10.1021/nn3008383

28. Chung Y-C, Su YP, Chen -C-C, et al. Relationship between antibacterial activity of chitosan and surface characteristics of cell wall. Acta Pharmacol Sin. 2004;25(7):932-936.

29. Gross M, Cramton SE, Götz F, Peschel A. Key role of teichoic acid net charge in staphylococcus aureus colonization of artificial surfaces. Infect Immun. 2001;69(5):3423-3426. doi:10.1128/ IAI.69.5.3423-3426.2001
30. Franci G, Falanga A, Galdiero S, et al. Silver nanoparticles as potential antibacterial agents. Molecules. 2015;20(5):8856-8874. doi:10.3390/molecules20058856

31. El Badawy AM, Silva RG, Morris B, Scheckel KG, Suidan MT, Tolaymat TM. Surface charge-dependent toxicity of silver nanoparticles. Environ Sci Technol. 2010;45(1):283-287. doi:10. $1021 / \mathrm{es} 1034188$

32. Abbaszadegan A, Ghahramani Y, Gholami A, et al. The effect of charge at the surface of silver nanoparticles on antimicrobial activity against Gram-positive and Gram-negative bacteria: a preliminary study. J Nanomater. 2015;16(1):53.

33. Liu L, Yang J, Xie J, et al. The potent antimicrobial properties of cell penetrating peptide-conjugated silver nanoparticles with excellent selectivity for Gram-positive bacteria over erythrocytes. Nanoscale. 2013;5(9):3834-3840. doi:10.1039/c3nr34254a

34. Guisbiers G, Wang Q, Khachatryan E, et al. Inhibition of E. coli and $\mathrm{S}$. aureus with selenium nanoparticles synthesized by pulsed laser ablation in deionized water. Int J Nanomed. 2016;11:3731. doi:10.2147/IJN.S106289

35. Boroumand S, Safari M, Shaabani E, Shirzad M, Faridi-Majidi R. Selenium nanoparticles: synthesis, characterization and study of their cytotoxicity, antioxidant and antibacterial activity. Mater Res Express. 2019;6(8):0850d8. doi:10.1088/2053-1591/ab2558

36. Yu B, Zhang Y, Zheng W, Fan C, Chen T. Positive surface charge enhances selective cellular uptake and anticancer efficacy of selenium nanoparticles. Inorg Chem. 2012;51(16):8956-8963. doi:10.1021/ic301050v

37. Silva T, Pokhrel LR, Dubey B, Tolaymat TM, Maier KJ, Liu X. Particle size, surface charge and concentration dependent ecotoxicity of three organo-coated silver nanoparticles: comparison between general linear model-predicted and observed toxicity. Sci Total Environ. 2014;468:968-976. doi:10.1016/j.scitotenv.2013.09.006

38. Buchman JT, Rahnamoun A, Landy KM, et al. Using an environmentally-relevant panel of Gram-negative bacteria to assess the toxicity of polyallylamine hydrochloride-wrapped gold nanoparticles. Environ Sci Nano. 2018;5(2):279-288. doi:10.1039/ C7EN00832E

39. Yoksan R, Chirachanchai S. Silver nanoparticle-loaded chitosanstarch based films: fabrication and evaluation of tensile, barrier and antimicrobial properties. Mater Sci Eng C. 2010;30(6):891-897. doi:10.1016/j.msec.2010.04.004

40. $\mathrm{Cu}$ TS, Nguyen CK, Tran NQ, Tran NQ. Preparation of silver core-chitosan shell nanoparticles using catechol-functionalized chitosan and antibacterial studies. Macromol Res. 2014;22 (4):418-423. doi:10.1007/s13233-014-2054-5

41. Nguyen VT, Tran KVQ, Tran QN. Effect of oligochitosan-coated silver nanoparticles (OCAgNPs) on the growth and reproduction of three species Phytophthora in vitro. Arch Phytopathol Plant Protect. 2018;51(4):227-240. doi:10.1080/03235408.2018.1458394

42. Clamme JP, Azoulay J, Mély Y. Monitoring of the formation and dissociation of polyethylenimine/DNA complexes by two photon fluorescence correlation spectroscopy. Biophys J. 2003;84 (3):1960-1968. doi:10.1016/S0006-3495(03)75004-8

43. Wytrwal M, Koczurkiewicz P, Wojcik K, et al. Synthesis of strong polycations with improved biological properties. J Biomed Mater Res A. 2014;102(3):721-731. doi:10.1002/jbm.a.34744

44. Dai T, Tanaka M, Huang -Y-Y, Hamblin MR. Chitosan preparations for wounds and burns: antimicrobial and wound-healing effects. Expert Rev Anti-Infect Ther. 2011;9(7):857-879. doi:10.1586/eri.11.59

45. El-Sherbiny I, Abdel-Bary E, Harding D. Swelling characteristics and in vitro drug release study with $\mathrm{pH}$ - and thermally sensitive hydrogels based on modified chitosan. J Appl Polym Sci. 2006;102 (2):977-985. doi:10.1002/app.23989

46. Kim S-K, Rajapakse N. Enzymatic production and biological activities of chitosan oligosaccharides (COS): A review. Carbohydr Polym. 2005;62(4):357-368. doi:10.1016/j.carbpol.2005.08.012 
47. Einbu A, Grasdalen H, Vårum KM. Kinetics of hydrolysis of chitin/ chitosan oligomers in concentrated hydrochloric acid. Carbohydr Res. 2007;342(8):1055-1062. doi:10.1016/j.carres.2007.02.022

48. Fai AEC, Stamford T, Stamford-Arnaud TM, et al. Physico-chemical characteristics and functional properties of chitin and chitosan produced by Mucor circinelloides using yam bean as substrate. Molecules. 2011;16(8):7143-7154. doi:10.3390/molecules16087143

49. Doblhofer E, Scheibel T. Engineering of recombinant spider silk proteins allows defined uptake and release of substances. J Pharm Sci. 2015;104(3):988-994. doi:10.1002/jps.24300

50. Petzold J, Aigner TB, Touska F, Zimmermann K, Scheibel T, Engel FB. Surface features of recombinant spider silk protein eADF4 (к16)-made materials are well-suited for cardiac tissue engineering. Adv Funct Mater. 2017;27(36):1701427. doi:10.1002/ adfm.201701427

51. Humenik M, Smith AM, Scheibel T. Recombinant spider silksbiopolymers with potential for future applications. Polymers. 2011;3(1):640-661. doi:10.3390/polym3010640

52. Müller-Herrmann S, Scheibel T. Enzymatic degradation of films, particles, and nonwoven meshes made of a recombinant spider silk protein. ACS Biomater Sci Eng. 2015;1(4):247-259. doi:10.1021/ ab500147u

53. Leal-Egaña A, Scheibel T. Silk-based materials for biomedical applications. Biotechnol Appl Biochem. 2010;55(3):155-167. doi:10.1042/BA20090229

54. Zeplin PH, Maksimovikj NC, Jordan MC, et al. Spider silk coatings as a bioshield to reduce periprosthetic fibrous capsule formation. $A d v$ Funct Mater. 2014;24(18):2658-2666. doi:10.1002/adfm.201302813

55. Huemmerich D, Helsen CW, Quedzuweit S, Oschmann J, Rudolph R, Scheibel T. Primary structure elements of spider dragline silks and their contribution to protein solubility. Biochemistry. 2004;43(42):13604-13612. doi:10.1021/bi048983q

56. Aigner TB, DeSimone E, Scheibel T. Biomedical applications of recombinant silk-based materials. Adv Mater. 2018;30 (19):1704636. doi:10.1002/adma.201704636

57. Shah C, Kumar M, Bajaj P. Acid-induced synthesis of polyvinyl alcohol-stabilized selenium nanoparticles. Nanotechnology. 2007;18(38):385607. doi:10.1088/0957-4484/18/38/385607

58. Shah CP, Singh KK, Kumar M, Bajaj PN. Vinyl monomers-induced synthesis of polyvinyl alcohol-stabilized selenium nanoparticles. Mater Res Bull. 2010;45(1):56-62. doi:10.1016/j.materresbull.2009.09.001

59. Tran PA, O’Brien-Simpson N, Palmer JA, et al. Selenium nanoparticles as anti-infective implant coatings for trauma orthopedics against methicillin-resistant Staphylococcus aureus and epidermidis: in vitro and in vivo assessment. Int J Nanomed. 2019;14:4613. doi:10.2147/IJN.S197737

60. Hinterwirth H, Wiedmer SK, Moilanen M, et al. Comparative method evaluation for size and size-distribution analysis of gold nanoparticles. J Sep Sci. 2013;36(17):2952-2961. doi:10.1002/jssc.201300460

61. Iso E. 10993-5: Biological Evaluation of Medical Devices. Tests for in vitro cytotoxicity; 2009.

62. Lam SJ, O’Brien-Simpson NM, Pantarat N, et al. Combating multidrug-resistant Gram-negative bacteria with structurally nanoengineered antimicrobial peptide polymers. Nat Microbiol. 2016;1(11):16162. doi:10.1038/nmicrobiol.2016.162

63. Agostini E, Winter G, Engert J. Scale-up of water-based spider silk film casting using a film applicator. Int J Pharm. 2017;532 (1):13-20. doi:10.1016/j.ijpharm.2017.08.090

64. Huemmerich D, Slotta U, Scheibel T. Processing and modification of films made from recombinant spider silk proteins. Appl Phys A. 2006;82(2):219-222. doi:10.1007/s00339-005-3428-5

65. ASTM. A D3359-17 Standard Test Methods for Rating Adhesion by Tape Test. West Conshohocken, PA: ASTM International; 2017.

66. Yin $\mathrm{Y}, \mathrm{Xu} \mathrm{H}$, Wang $\mathrm{Y}$, et al. Improving adhesion between nanoparticles and surface of mica substrate by aminosilane modification. Plasmonics. 2019;1-9.
67. Helfricht N, Doblhofer E, Bieber V, et al. Probing the adhesion properties of alginate hydrogels: a new approach towards the preparation of soft colloidal probes for direct force measurements. Soft Matter. 2017;13(3):578-589. doi:10.1039/C6SM02326F

68. DiPaolo J, Takano K, Popescu N. Quantitation of chemically induced neoplastic transformation of BALB/3T3 cloned cell lines. Cancer Res. 1972;32(12):2686-2695.

69. Terpiłowska S, Siwicka-Gieroba D, Siwicki AK. Cytotoxicity of iron (III), molybdenum (III), and their mixtures in BALB/3T3 and HepG2 cells. J Vet Res. 2018;62(4):527-533. doi:10.2478/jvetres2018-0066

70. Uboldi C, Urbán P, Gilliland D, et al. Role of the crystalline form of titanium dioxide nanoparticles: rutile, and not anatase, induces toxic effects in Balb/3T3 mouse fibroblasts. Toxicol in Vitro. 2016;31:137-145. doi:10.1016/j.tiv.2015.11.005

71. Pelin M, Fusco L, Martín C, et al. Graphene and graphene oxide induce ROS production in human HaCaT skin keratinocytes: the role of xanthine oxidase and NADH dehydrogenase. Nanoscale. 2018;10(25):11820-11830. doi:10.1039/C8NR02933D

72. Sighinolfi G, Artoni E, Gatti A, Corsi L. Carcinogenic potential of metal nanoparticles in BALB/3 T 3 cell transformation assay. Environ Toxicol. 2016;31(5):509-519. doi:10.1002/tox.22063

73. Paolini A, Guarch CP, Ramos-López D, et al. Rhamnose-coated superparamagnetic iron-oxide nanoparticles: an evaluation of their in vitro cytotoxicity, genotoxicity and carcinogenicity. $J \mathrm{Appl}$ Toxicol. 2016;36(4):510-520. doi:10.1002/jat.3273

74. Senthil B, Devasena T, Prakash B, Rajasekar A. Non-cytotoxic effect of green synthesized silver nanoparticles and its antibacterial activity. $J$ Photochem Photobiol B Biol. 2017;177:1-7. doi:10.1016/j.jphotobiol.2017.10.010

75. Zeng H, Combs GF. Selenium as an anticancer nutrient: roles in cell proliferation and tumor cell invasion. J Nutr Biochem. 2008;19 (1):1-7. doi:10.1016/j.jnutbio.2007.02.005

76. Fröhlich E. The role of surface charge in cellular uptake and cytotoxicity of medical nanoparticles. Int $J$ Nanomed. 2012;7:5577. doi:10.2147/IJN.S36111

77. Ciani L, Ristori S, Bonechi C, Rossi C, Martini G. Effect of the preparation procedure on the structural properties of oligonucleotide/ cationic liposome complexes (lipoplexes) studied by electron spin resonance and Zeta potential. Biophys Chem. 2007;131(1-3):80-87. doi:10.1016/j.bpc.2007.09.011

78. Patil S, Sandberg A, Heckert E, Self W, Seal S. Protein adsorption and cellular uptake of cerium oxide nanoparticles as a function of zeta potential. Biomaterials. 2007;28(31):4600-4607. doi:10.1016/ j.biomaterials.2007.07.029

79. Chen -C-C, Tsai T-H, Huang Z-R, Fang J-Y. Effects of lipophilic emulsifiers on the oral administration of lovastatin from nanostructured lipid carriers: physicochemical characterization and pharmacokinetics. Eur J Pharm Biopharm. 2010;74(3):474-482. doi:10.1016/j.ejpb.2009.12.008

80. Bernfield M, Götte M, Park PW, et al. Functions of cell surface heparan sulfate proteoglycans. Annu Rev Biochem. 1999;68 (1):729-777. doi:10.1146/annurev.biochem.68.1.729

81. Honary S, Zahir F. Effect of zeta potential on the properties of nano-drug delivery systems-a review (Part 1). Trop J Pharm Res. 2013;12(2):255-264.

82. Hamouda T, Baker JJ. Antimicrobial mechanism of action of surfactant lipid preparations in enteric Gram-negative bacilli. $\mathrm{J} \mathrm{Appl}$ Microbiol. 2000;89(3):397-403. doi:10.1046/j.13652672.2000.01127.x

83. Mempin R, Tran H, Chen C, Gong H, Ho KK, Lu S. Release of extracellular ATP by bacteria during growth. BMC Microbiol. 2013;13(1):301. doi:10.1186/1471-2180-13-301

84. Lok C-N, Ho C-M, Chen R, et al. Silver nanoparticles: partial oxidation and antibacterial activities. JBIC J Biol Inorg Chem. 2007;12(4):527-534. doi:10.1007/s00775-007-0208-z 
85. Applerot G, Lipovsky A, Dror R, et al. Enhanced antibacterial activity of nanocrystalline $\mathrm{ZnO}$ due to increased ROS-mediated cell injury. Adv Funct Mater. 2009;19(6):842-852. doi:10.1002/ adfm.200801081

86. Tong G, Du F, Wu W, Wu R, Liu F, Liang Y. Enhanced reactive oxygen species (ROS) yields and antibacterial activity of spongy $\mathrm{ZnO} /$ $\mathrm{ZnFe} 2 \mathrm{O} 4$ hybrid micro-hexahedra selectively synthesized through a versatile glucose-engineered co-precipitation/annealing process. J Mater ChemB. 2017;27(36):1701427-1701457. doi:10.1039/c3tb20 $229 \mathrm{a}$

87. Páez PL, Becerra MC, Albesa I. Impact of ciprofloxacin and chloramphenicol on the lipid bilayer of Staphylococcus aureus: changes in membrane potential. Biomed Res Int. 2013;2013:276524. doi:10. $1155 / 2013 / 276524$

88. Chudobova D, Cihalova K, Dostalova S, et al. Comparison of the effects of silver phosphate and selenium nanoparticles on Staphylococcus aureus growth reveals potential for selenium particles to prevent infection. FEMS Microbiol Lett. 2014;351(2):195-201. doi:10.1111/1574-6968.12353

89. Liu W, Golshan NH, Deng X, et al. Selenium nanoparticles incorporated into titania nanotubes inhibit bacterial growth and macrophage proliferation. Nanoscale. 2016;8(34):15783-15794. doi:10. 1039/C6NR04461A

90. Webster TJ, Tran PA. Antipathogenic Surfaces Having Selenium Nanoclusters. Google Patents; 2016.

91. Xing $\mathrm{X}, \mathrm{Ma} \mathrm{W}$, Zhao $\mathrm{X}$, et al. Interaction between surface charge-modified gold nanoparticles and phospholipid membranes. Langmuir. 2018;34(42):12583-12589. doi:10.1021/acs.langmuir. $8 \mathrm{~b} 01700$

92. Banerjee M, Sharma S, Chattopadhyay A, Ghosh SS. Enhanced antibacterial activity of bimetallic gold-silver core-shell nanoparticles at low silver concentration. Nanoscale. 2011;3(12):5120-5125. doi:10.1039/c1nr10703h
93. Fayaz AM, Balaji K, Girilal M, Yadav R, Kalaichelvan PT, Venketesan R. Biogenic synthesis of silver nanoparticles and their synergistic effect with antibiotics: a study against gram-positive and gram-negative bacteria. Nanomed Nanotechnol Biol Med. 2010;6(1):103-109. doi:10.1016/j.nano.2009.04.006

94. Beladi M, Sepahi AA, Mehrabian S, Esmaeili A, Sharifnia F. Antibacterial activities of selenium and selenium nano-particles (products from Lactobacillus acidophilus) on nosocomial strains resistant to antibiotics. J Pure Appl Microbiol. 2015;9(4):2843-2852.

95. Huang X, Chen X, Chen Q, Yu Q, Sun D, Liu J. Investigation of functional selenium nanoparticles as potent antimicrobial agents against superbugs. Acta Biomater. 2016;30:397-407. doi:10.1016/ j.actbio.2015.10.041

96. Wiegand I, Hilpert K, Hancock RE. Agar and broth dilution methods to determine the minimal inhibitory concentration (MIC) of antimicrobial substances. Nat Protoc. 2008;3(2):163. doi:10.1038/ nprot. 2007.521

97. EUCAST. Determination of minimum inhibitory concentrations (MICs) of antibacterial agents by broth dilution. Clin Microbiol Infect. 2003;9(8):ix-xv. doi:10.1046/j.1469-0691.2003.00790.x

98. CLSI. Methods for Dilution Antimicrobial Susceptibility Tests for Bacteria That Grow Aerobically; Approved Standard: M07-A10. Wayne, PA: Clinical and Laboratory Standards Institute; 2015.

99. Borkner CB, Wohlrab S, Möller E, Lang G, Scheibel T. Surface modification of polymeric biomaterials using recombinant spider silk proteins. ACS Biomater Sci Eng. 2016;3(5):767-775. doi:10.1021/acsbiomaterials.6b00306

100. Eby DM, Luckarift HR, Johnson GR. Hybrid antimicrobial enzyme and silver nanoparticle coatings for medical instruments. ACS Appl Mater Interfaces. 2009;1(7):1553-1560. doi:10.1021/am9002155

101. Milosavljevic V, Cihalova K, Horky P, Richtera L, Adam V, Adam V. Selenium nanoparticles as a nutritional supplement. Nutrition. 2017;33:83-90. doi:10.1016/j.nut.2016.05.001
International Journal of Nanomedicine

\section{Publish your work in this journal}

The International Journal of Nanomedicine is an international, peerreviewed journal focusing on the application of nanotechnology in diagnostics, therapeutics, and drug delivery systems throughout the biomedical field. This journal is indexed on PubMed Central, MedLine, CAS, SciSearch ${ }^{\mathbb{}}$, Current Contents ${ }^{\mathbb{R}} /$ Clinical Medicine,
Journal Citation Reports/Science Edition, EMBase, Scopus and the Elsevier Bibliographic databases. The manuscript management system is completely online and includes a very quick and fair peer-review system, which is all easy to use. Visit http://www.dovepress.com/ testimonials.php to read real quotes from published authors. 